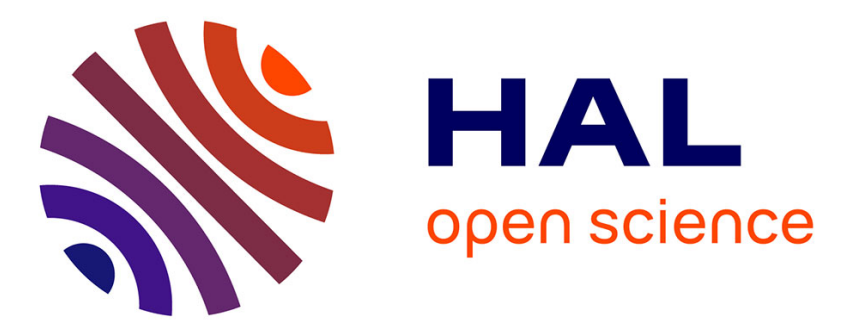

\title{
Achieving visible light-driven hydrogen evolution at positive bias with a hybrid copper-iron oxide|TiO2-cobaloxime photocathode
}

C. Tapia, E. Bellet-Amalric, D. Aldakov, F. Boudoire, K. Sivula, Laurent Cagnon, V. Artero

\section{To cite this version:}

C. Tapia, E. Bellet-Amalric, D. Aldakov, F. Boudoire, K. Sivula, et al.. Achieving visible light-driven hydrogen evolution at positive bias with a hybrid copper-iron oxide|TiO2-cobaloxime photocathode. Green Chemistry, 2020, 22 (10), pp.3141-3149. 10.1039/d0gc00979b . hal-02877560

\author{
HAL Id: hal-02877560 \\ https://hal.science/hal-02877560
}

Submitted on 2 Oct 2020

HAL is a multi-disciplinary open access archive for the deposit and dissemination of scientific research documents, whether they are published or not. The documents may come from teaching and research institutions in France or abroad, or from public or private research centers.
L'archive ouverte pluridisciplinaire HAL, est destinée au dépôt et à la diffusion de documents scientifiques de niveau recherche, publiés ou non, émanant des établissements d'enseignement et de recherche français ou étrangers, des laboratoires publics ou privés. 


\section{PAPER}

Cite this: DOI: $10.1039 / \mathrm{d0gc00979b}$

\section{Achieving visible light-driven hydrogen evolution at positive bias with a hybrid copper-iron oxidel $\mathrm{TiO}_{2}$-cobaloxime photocathode $\uparrow$}

\author{
C. Tapia, (D) a E. Bellet-Amalric, ${ }^{b}$ D. Aldakov, (D) ${ }^{c}$ F. Boudoire, ${ }^{d}$ K. Sivula, (D) d \\ L. Cagnon ${ }^{\mathrm{e}}$ and V. Artero (ID *a
}

$\mathrm{H}_{2}$ is an environmentally-friendly fuel that would allow for a circular economy but its sustainable production, e.g. from solar energy and water, remains a challenge. A hybrid $\mathrm{CuFe}_{x} \mathrm{O}_{y} \mid \mathrm{TiO}_{2}-\mathrm{CoHEC}(\mathrm{CoHEC}=$ chloro([4,4'-bipyridine]-2,6-dicarboxylic acid)bis(dimethylglyoximato)cobalt(III)) photocathode for hydrogen evolution reaction (HER), with faradaic efficiencies of $54-88 \%$, is described, the preparation of which uses only non-toxic and Earth-abundant elements, avoids etching treatments and limits the use of organic solvents. The semi-conducting $\mathrm{CuFe}_{x} \mathrm{O}_{y}$ light absorber is obtained by sol-gel synthesis followed by calcination at moderate temperature. Grafting the COHEC cobaloxime catalyst at its surface results in $\mathrm{H}_{2}$ evolution with an onset photocurrent potential of $+860 \mathrm{mV}$; this process being stabilized by the presence of a thin layer of amorphous $\mathrm{TiO}_{2}$ deposited onto $\mathrm{CuFe}_{x} \mathrm{O}_{y}$.
Received 19th March 2020,

Accepted 21st April 2020

DOI: $10.1039 / \mathrm{dOgc00979b}$

rsc.li/greenchem tation and (iii) good stability in contact with aqueous electrolytes. Here, we focus on the design of an efficient photocathode for hydrogen evolution, for which fewer solutions exist. Indeed, the large majority of studies have focused on $\mathrm{Cu}_{2} \mathrm{O}^{5-8}$ and p-doped $\mathrm{Si}^{9,10}$ as photocathode candidates due to their narrow band-gaps, adequate band positions, and Earth abundancy. However, the flat-band potential of p-Si combined with the low photovoltage associated to its low band-gap directly affects the onset photocurrent potential, which is not positive enough for standalone photoelectrochemical watersplitting. In addition, both p-Si and $\mathrm{Cu}_{2} \mathrm{O}$ suffer from the lack of photostability and require ultra-efficient protective coating to avoid oxidation and photo reduction, respectively. Other solutions exploit critical elements such as indium and gallium. ${ }^{11,12}$ Silicon and III-V semiconductors exhibit limited stability in aqueous solutions and must be thoroughly passivated after HF etching of native oxide layer. ${ }^{9,10,13-15}$ Metal oxides hold promises in that prospect. ${ }^{5,16}$ Unfortunately, copper oxides suffer from photocorrosion if they are not efficiently protected. To overcome this limitation, the interest has shifted to $\mathrm{ABO}_{x}$ ternary metal oxides, in which the insertion of a B cation (such Fe, V, Bi, Cr) can perturb the electronic band structure enough to stabilize copper oxides against photocorrosion..$^{17}$ In particular $\mathrm{CuFeO}_{2}$ delafossite, exclusively based on Earth-abundant elements, has a 1.5-1.6 eV bandgap suitable for absorption of visible light and a conduction band positioned negative enough to allow for hydrogen evolution. ${ }^{18-21}$ Only few studies were reported so far toward the use of this material in a photocathode for $\mathrm{H}_{2}$ evolution,
${ }^{a}$ Univ. Grenoble Alpes, CNRS, CEA IRIG, Laboratoire de Chimie et Biologie des Métaux, F-38000 Grenoble, France. E-mail: vincent.artero@cea.fr

${ }^{b}$ Univ. Grenoble Alpes, CNRS, CEA IRIG, PHELIQS, F-38000 Grenoble, France ${ }^{c}$ Univ. Grenoble Alpes, CNRS, CEA IRIG-SyMMES, F-38000 Grenoble, France

${ }^{d}$ Laboratory for Molecular Engineering of Optoelectronic Nanomaterials,

École Polytechnique Fédérale de Lausanne (EPFL), Station 6, 1015 Lausanne, Switzerland

${ }^{e}$ Univ. Grenoble Alpes - CNRS UPR 2940, Institut NEEL, F-38000 Grenoble, France $\dagger$ Electronic supplementary information (ESI) available. See DOI: 10.1039/ d0gc00979b 


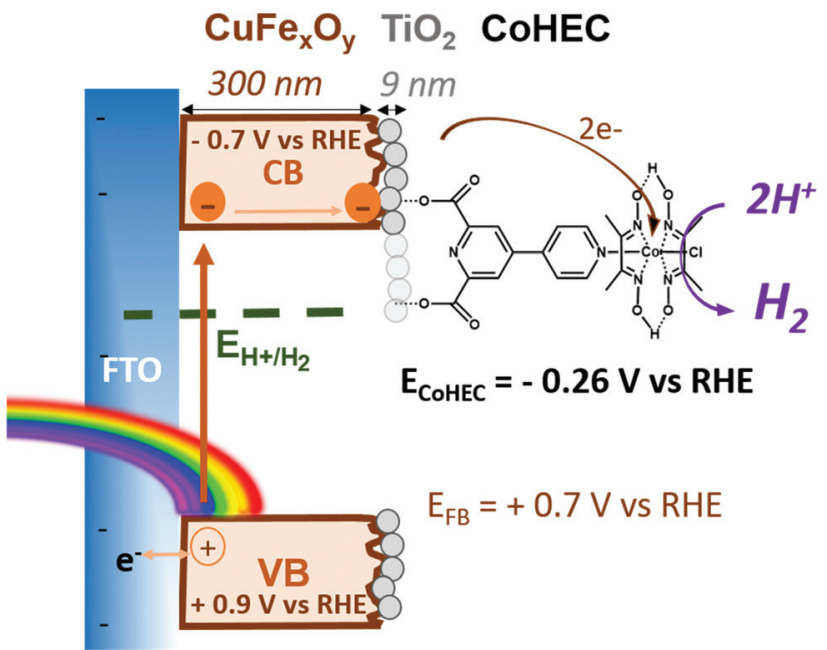

Fig. 1 Scheme of electron pathway on $\mathrm{CuFe}_{x} \mathrm{O}_{y} \mid \mathrm{TiO}_{2}-\mathrm{CoHEC}$ photocathode and energy potentials.

and combining this photoactive material with a surface catalyst to enhance its photochemical properties has not been explored so far. Recently, we and others have demonstrated that cobalt diimine-dioxime ${ }^{22-25}$ or cobaloximes, ${ }^{25-29}$ with proper anchoring groups can be used as molecular electrocatalysts for $\mathrm{H}_{2}$ evolution in metal oxide-based photocathodes. Therefore, we decided to exploit the CoHEC cobaloxime catalyst (Fig. 1) to decorate photoactive copper-iron oxide materials towards the elaboration of a $\mathrm{H}_{2}$-evolving photocathode and found that good performance could be reached with the deposition of a thin layer of amorphous $\mathrm{TiO}_{2}$ as a protective coating. ${ }^{23,26}$ Fig. 1 displays the structure and electronics of such a hybrid architecture. The protection of the $\mathrm{Cu}-\mathrm{Fe}$ oxide layer with a thin layer of amorphous $\mathrm{TiO}_{2}$ allows to photoproduce $\mathrm{H}_{2}$ with faradaic efficiencies of $54-88 \%$ and with onset potential as high as $0.4 \mathrm{~V}$ vs. RHE in neutral aqueous electrolyte under pure visible light irradiation. Such a hybrid approach ${ }^{30}$ thus proves a competitive and greener alternative to dye-sensitized photoelectrodes ${ }^{25,31,32}$ with the advantage of avoiding the dye preparation and sensitizing steps.

\section{Experimental section}

\section{Materials}

Fluorine-doped tin oxide (FTO) coated glass substrates were purchased from Solems (Palaiseau, France). Acetone, absolute ethanol, copper nitrate trihydrate, iron nitrate nonahydrate, ethylene glycol, methanol, poly(ethylene glycol)-block-poly(propylene glycol)-block-poly(ethylene glycol) (F-108) and potassium phosphate were purchased from Sigma-Aldrich. Chloro ([4,4'-bipyridine]-2,6-dicarboxylic acid)bis(dimethylglyoximato) cobalt(III) (CoHEC) was purchased from Dyenamo (Sweden). Titanium(IV) isopropoxide (TTIP) was purchased from Strem
Chemicals Inc. All the reagents were used as received without further purification.

\section{Photocathode preparation}

$\mathrm{Cu}$-Fe oxide $\left(\mathrm{CuFe}_{x} \mathrm{O}_{y}\right)$ deposition on FTO glass substrates. The procedure was adapted from previously reported studies. ${ }^{18,33}$ Glass|FTO substrates $\left(20 \times 40 \mathrm{~mm}^{2}\right)$ were cleaned first with soap and water, then with ethanol and finally with acetone, each step during 15 minutes in an ultrasonic bath. Then, they were treated in an UV-ozone cleaner during 15 minutes. A mixture of $0.2 \mathrm{M} \mathrm{Cu}\left(\mathrm{NO}_{3}\right)_{2} \cdot 3 \mathrm{H}_{2} \mathrm{O}, 0.2 \mathrm{M}$ Fe $\left(\mathrm{NO}_{3}\right)_{3} \cdot 9 \mathrm{H}_{2} \mathrm{O}$ and $0.45 \mathrm{M}$ ethylene glycol in ethanol was spin coated on glass|FTO substrates at $3300 \mathrm{rpm}$ during 1 minute followed for $600 \mathrm{rpm}$ during 30 seconds, following a protocol previously reported. ${ }^{21}$ The substrates were placed in a flat titanium furnace and heated up to $200{ }^{\circ} \mathrm{C}$ in the air during 30 minutes to stabilize the film. The spin coating and the heating processes were repeated 5 times for each glass|FTO substrate. A last annealing step at $450{ }^{\circ} \mathrm{C}$ for 30 minutes and then at $600{ }^{\circ} \mathrm{C}$ for 2 hours in a tubular furnace under argon flow was performed to eliminate all organic residues, reduce $\mathrm{Cu}(\mathrm{II})$ to $\mathrm{Cu}(\mathrm{I})$ and crystalize the $\mathrm{Cu}-\mathrm{Fe}$ oxide films $\left(\mathrm{CuFe}_{x} \mathrm{O}_{y \text { FLAT }}\right) \cdot{ }^{18,33}$ In some cases, the sixth layer was structured in order to increase the surface area of the $\mathrm{CuFe}_{x} \mathrm{O}_{y}$ electrode. Here, F-108 polymer $\left(120 \mathrm{mg} \mathrm{mL}^{-1}\right)$ was added to the solution used for fabricate the sixth layer. ${ }^{25}$ We will refer to these layers as $\mathrm{CuFe}_{x} \mathrm{O}_{y \text { STRUCT. }}$.

Deposition of amorphous $\mathrm{TiO}_{2}$ by atomic layer deposition (ALD). $\mathrm{TiO}_{2}$ was deposited on $\mathrm{CuFe}_{x} \mathrm{O}_{y \text { FLAT }}$ electrodes by ALD (Savannah 100 ALD system, Cambridge Nano Tech Inc.) with precursor temperature at $95{ }^{\circ} \mathrm{C}$, pump line temperature at $150{ }^{\circ} \mathrm{C}$ and sample chamber temperature at $255^{\circ} \mathrm{C}$ in continuous mode under $5 \mathrm{sccm}$ nitrogen flow. TTIP was used as $\mathrm{Ti}$ source and water as $\mathrm{O}$ source. 355 cycles were applied, each cycle being composed of $1 \mathrm{~s}$ pulse of TTIP, $5 \mathrm{~s}$ pause, $0.015 \mathrm{~s}$ pulse of water and $5 \mathrm{~s}$ pause. The resulting electrodes are referred to as $\mathrm{CuFe}_{x} \mathrm{O}_{y} \mid \mathrm{TiO}_{2}$.

CoHEC grafting on $\mathrm{CuFe}_{x} \mathrm{O}_{y \text { STRUCT }}$ and $\mathrm{CuFe}_{x} \mathrm{O}_{y} \mid \mathrm{TiO}_{2}$. $\mathrm{CuFe}_{x} \mathrm{O}_{y \text { STRUCT }}$ and $\mathrm{CuFe}_{x} \mathrm{O}_{y} \mid \mathrm{TiO}_{2}$ electrodes were immersed in $0.7 \mathrm{mM}$ CoHEC methanol solution overnight, then rinsed with methanol and dried in air before use.

\section{Characterization techniques}

UV-visible absorption spectra of $\mathrm{CuFe}_{x} \mathrm{O}_{y}$ and $\mathrm{CuFe}_{x} \mathrm{O}_{y} \mid \mathrm{TiO}_{2}$ (before and after CoHEC grafting) were recorded with an Agilent Technologies Cary 60 UV-Vis spectrometer. The baseline corresponding to the glass|FTO support was recorded and automatically subtracted from the spectrum of the electrode.

Scanning electron microscopy (SEM) images showing the electrode morphology were recorded with a scanning electron microscope Zeiss Ultra 55 operating at $4 \mathrm{kV}$.

XRD measurement where performed on a Smartlab Rigaku diffractometer in glancing incidence: the incident beam was fixed at low angle (1 degree) to maximize the signal of the thin layer. The measurements correspond to a $2 \theta$ scan. 
Film-thickness measurements were performed with a laser scanning microscope VK-X120 (Keyence), using VK Viewer and VK Analyser softwares.

An ellipsometer (M 2000 model) from J. A. Woollam Co., In. was used to measure the thickness of the $\mathrm{ALD}-\mathrm{TiO}_{2}$ substrate, using the CompleteEASE software (V4.72). It was used in the "off-sample" configuration with an incident angle of attack of $75^{\circ}$ with respect to the film plane normal, and the light wavelength was scanned between $200 \mathrm{~nm}$ and $1700 \mathrm{~nm}$. The obtained data were fitted with the CompleteEASE software (V4.72).

X-ray photoelectron spectroscopy (XPS) analyses were carried out with a Versa Probe II spectrometer (ULVAC-PHI)

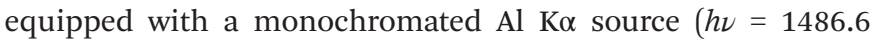
$\mathrm{eV})$. The core level peaks were recorded with constant pass energy of $23.3 \mathrm{eV}$. The XPS spectra were fitted with CasaXPS 2.3 software using Shirley background. Binding energies are referenced with respect to the adventitious carbon $(\mathrm{C} 1 \mathrm{~s} \mathrm{BE}=$ $284.6 \mathrm{eV}$ ).

Inductively coupled plasma atomic emission spectroscopy (ICP-AES) was performed using a Shimadzu ICPE-9000 instrument with a mini plasma torch in axial reading mode. The sample preparation involves the digestion overnight of the samples $\mathrm{CuFe}_{x} \mathrm{O}_{y}, \mathrm{CuFe}_{x} \mathrm{O}_{y}$-CoHEC, $\mathrm{CuFe}_{x} \mathrm{O}_{y} \mid \mathrm{TiO}_{2}$-CoHEC and $\mathrm{CuFe}_{x} \mathrm{O}_{y}$-CoHEC before and after chronoamperometry treatment in $1 \mathrm{~mL}$ of $\mathrm{HNO}_{3}(64 \%)$.

\section{Photoelectrochemical and hydrogen production measurements}

Electrochemical data were acquired with a Biologic VSP 300 (Linear scan voltammetry), an IVIUM compact potentiostat (chronoamperometry) and Autolab potentiostast with FRA module (electrochemical impedance spectroscopy - EIS). All measurements were carried out in a three electrode (photo) electrochemical cell, filled with pH 6.7 0.2 M phosphate buffer as electrolyte. A titanium wire was used as counter electrode (CE) and a $\mathrm{Ag} / \mathrm{AgCl}(3 \mathrm{M} \mathrm{KCl})$ electrode as reference electrode (RE). Potentials are referred to RHE by using the equation $(E=$ $0.200 \mathrm{~V}+0.059 \times \mathrm{pH})$. Calibration of the reference electrode was realized with $\left[\mathrm{K}_{4} \mathrm{Fe}(\mathrm{CN})_{6}\right]$ in $0.1 \mathrm{M}$ potassium phosphate buffer at $\mathrm{pH} 7 .^{34}$ Argon or nitrogen was bubbled to the electrolyte for 20 minutes to remove the oxygen before any electrochemical measurement. The geometrical active surface area was $0.5 \mathrm{~cm}^{2}$. The electrical contact in the working electrode was from the FTO part. EIS measurements were conducted in $0.2 \mathrm{M}$ phosphate $\mathrm{pH} 6.7$ at $10 \mathrm{kHz}$ and $0.4-0.7 \mathrm{~V} v s$. RHE potential range.

For photoelectrochemical measurements, a $280 \mathrm{~W}$ Xe lamp was used to irradiate the electrodes with 1 sun filtered so that only the visible part of the spectrum reaches the photoelectrode $\left(400-780 \mathrm{~nm}, 65 \mathrm{~mW} \mathrm{~cm}{ }^{-2}\right)$. UV irradiation was filtered with a Spectra-Physics $59472(\lambda<400 \mathrm{~nm})$ cut off filter and IR irradiation was filtered by a Spectra-Physics $6123 \mathrm{NS}$ circulating water filter kept at $25^{\circ} \mathrm{C}$. Chronoamperometric measurements were performed in a previously described cell with $4 \mathrm{~mL}$ electrolyte volume and $2.5 \mathrm{~cm}^{2}$ geometrical active surface area. ${ }^{35}$
The working electrode was connected with conductive silver paste to a wire, and the cell was completely isolated from air. Hydrogen production was determined by a hydrogen probe from Unisense, polarized at $1 \mathrm{~V} v s$. $\mathrm{Ag} / \mathrm{AgCl}$, and calibrated following the procedure described in our previous publication. ${ }^{35}$ It was placed inside the photo-electrochemical cell before and after the chronoamperometry to measure the amount of hydrogen in solution. ${ }^{35}$

\section{Results and discussion}

Different photocathodes for the hydrogen evolution reaction (HER) were prepared following the three-step strategy displayed in Fig. 2. First, the copper-iron oxide $\left(\mathrm{CuFe}_{x} \mathrm{O}_{y}\right)$ thin layers were prepared by sol-gel method from a mixture of copper and iron salts and spin-coated on glass|FTO substrates, following previous reports $^{18,33}$ as described in the Experimental section. Then, amorphous $\mathrm{TiO}_{2}$ was deposited on $\mathrm{CuFe}_{x} \mathrm{O}_{y}$ layers by ALD. Afterwards, the CoHEC cobaloxime catalyst was grafted on the top of $\mathrm{CuFe}_{x} \mathrm{O}_{y} \mid \mathrm{TiO}_{2}$ samples by overnight soaking into methanolic solution. On another batch of samples, $\mathrm{CuFe}_{x} \mathrm{O}_{y}$ layer was nanostructured $\left(\mathrm{CuFe}_{x} \mathrm{O}_{y \text { STRUCT }}\right)$ using the F108 triblock co-polymer template and the catalyst is grafted at the surface of $\mathrm{CuFe}_{x} \mathrm{O}_{y \text { stRuct }}$ without amorphous $\mathrm{TiO}_{2}$ deposition.

\section{Characterization of the $\mathrm{Cu}-\mathrm{Fe}$ oxide $\left(\mathrm{CuFe}_{x} \mathrm{O}_{y}\right)$ layers}

Brown colored $\mathrm{CuFe}_{x} \mathrm{O}_{y \text { FLAT }}$ six-layered samples were obtained after several spin-coating deposition and annealing cycles as described in the Experimental section. Observation by SEM revealed a single thin film of $221 \pm 30 \mathrm{~nm}$ thickness (Fig. 3A) without nanostructuration (Fig. 3Ac). The low active surface area of the electrode could result in poor catalyst loading in further steps.

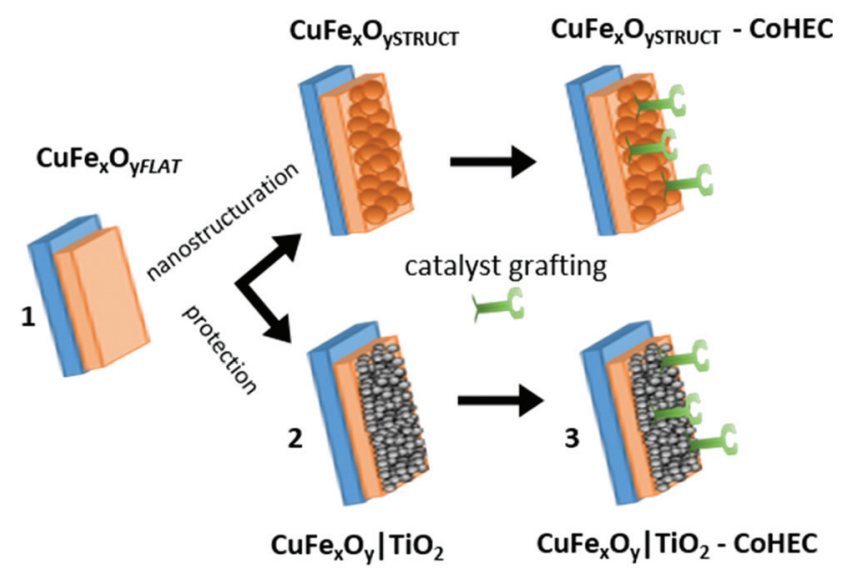

Fig. 2 Three-step preparation of the $\mathrm{CuFe}_{x} \mathrm{O}_{y \text { STRUCT-CoHEC and }}$ $\mathrm{CuFe}_{x} \mathrm{O}_{y} \mid \mathrm{TiO}_{2}$-CoHEC photocathodes: (1) synthesis of multi-layered $\mathrm{CuFe}_{x} \mathrm{O}_{y}$ light-harvesting semiconductor samples; (2) protection of the semiconductor with $\mathrm{TiO}_{2}$ or $\mathrm{CuFe}_{x} \mathrm{O}_{y}$ nanostructuration, and (3) grafting of the COHEC molecular catalyst. 
A

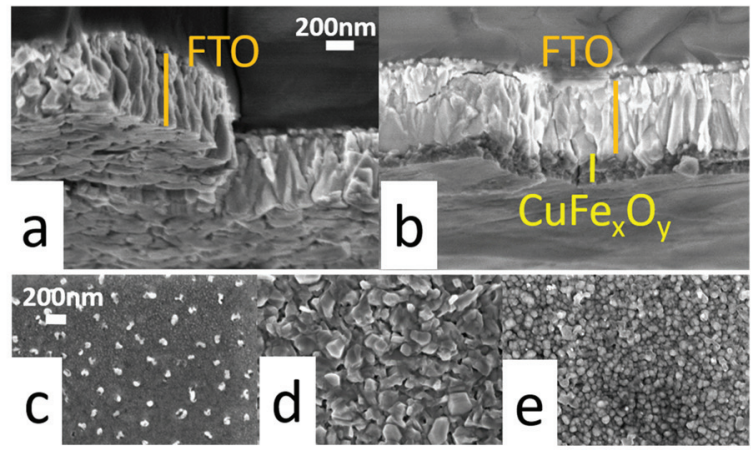

B

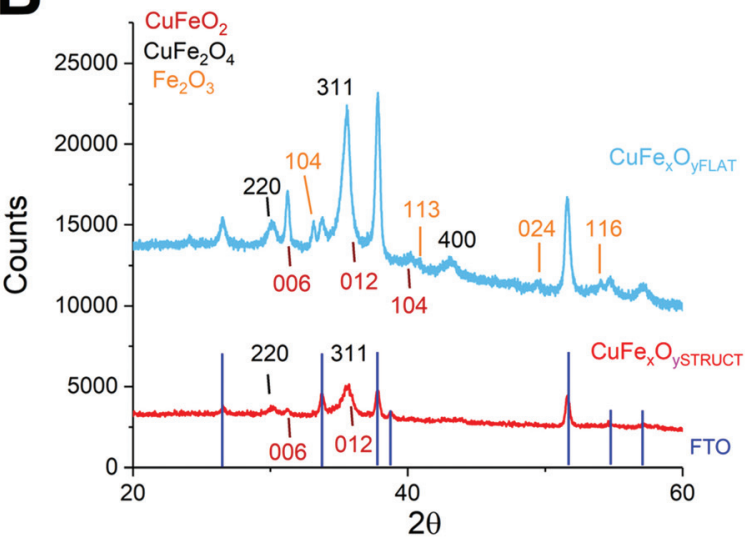

Fig. 3 (A) SEM sectional images from (a) clean FTO and (b) CuFe $\mathrm{O}_{y \text { FLAT }}$ layer synthetized on FTO (same scale). SEM front images from (c) $\mathrm{CuFe}_{x} \mathrm{O}_{y \mathrm{FLAT}}$, (d) $\mathrm{CuFe}_{x} \mathrm{O}_{y \text { STRUCT }}$ and (e) $\mathrm{CuFe}_{x} \mathrm{O}_{y} \mid \mathrm{TiO}_{2}$ (same scale). (B) XRD pattern of $\mathrm{CuFe}_{x} \mathrm{O}_{y \mathrm{FLAT}}$ in blue, $\mathrm{CuFe}_{x} \mathrm{O}_{y \text { STRUCT }}$ in red and FTO in dark blue. All peaks are referenced to delafossite $\mathrm{CuFeO}_{2}$ (JCPDS 04015-2087) (brown); spinel $\mathrm{CuFe}_{2} \mathrm{O}_{4}$ (JCPDS 01-074-8585) (black) and $\mathrm{Fe}_{2} \mathrm{O}_{3}$ (JCPDS 04-003-2900) (orange).

The addition of a triblock polymer known as F-108 in the sol-gel used for the sixth and last cycle resulted in higher nanostructuration ( $\mathrm{CuFe}_{x} \mathrm{O}_{y \text { STRUCT }}$, Fig. 2 and 3Ad). This top layer with a thickness of $137 \pm 9 \mathrm{~nm}$ (Fig. S1 $\dagger$ ) displayed a grain size around 100-200 $\mathrm{nm}$ in diameter (Fig. 3Ad). The total thickness of $\mathrm{CuFe}_{x} \mathrm{O}_{y \text { STRUCT }}$ was estimated to $320 \pm 40 \mathrm{~nm}$.

The $\mathrm{Cu}$ : Fe atomic ratio measured by EDX on $\mathrm{CuFe}_{x} \mathrm{O}_{y \text { FLAT }}$ thin film was $1: 1.3$ (Fig. S2 $\dagger$ ), indicating a copper-deficient delafossite $\mathrm{CuFeO}_{2}$ structure. XRD revealed that $\mathrm{CuFe}_{x} \mathrm{O}_{y \text { FLAT }}$ electrodes contain a rhombohedral delafossite $\mathrm{CuFeO}_{2}$ (JCPDS 04-015-2087) phase together with cubic spinel $\mathrm{CuFe}_{2} \mathrm{O}_{4}$ (JCPDS 01-074-8585) and $\mathrm{Fe}_{2} \mathrm{O}_{3}$ (JCPDS 04-003-2900) parasitic phase (Fig. 3B). These results were confirmed by Raman spectroscopy performed in $\mathrm{CuFe}_{x} \mathrm{O}_{y \text { FLAT }}$ and $\mathrm{CuFe}_{x} \mathrm{O}_{y \text { STRUCT }}$ (Fig. S3 $\dagger$ ). $\mathrm{CuFe}_{2} \mathrm{O}_{4}$ is first formed from $\mathrm{CuO}$ and $\mathrm{Fe}_{2} \mathrm{O}_{3}$, which are formed from the same sol-gel precursor solution before reaching $180{ }^{\circ} \mathrm{C}$ and around $300{ }^{\circ} \mathrm{C}$, respectively. ${ }^{33,36}$ Afterwards, the spinel $\mathrm{CuFe}_{2} \mathrm{O}_{4}$ phase can be converted with $\mathrm{CuO}$ during the last annealing step and form $\mathrm{CuFeO}_{2}$ delafossite with no need of additional reductant agent. ${ }^{37}$ The presence of $\mathrm{CuFe}_{2} \mathrm{O}_{4}$ in our films suggests this last step is not fully achieved. The
A
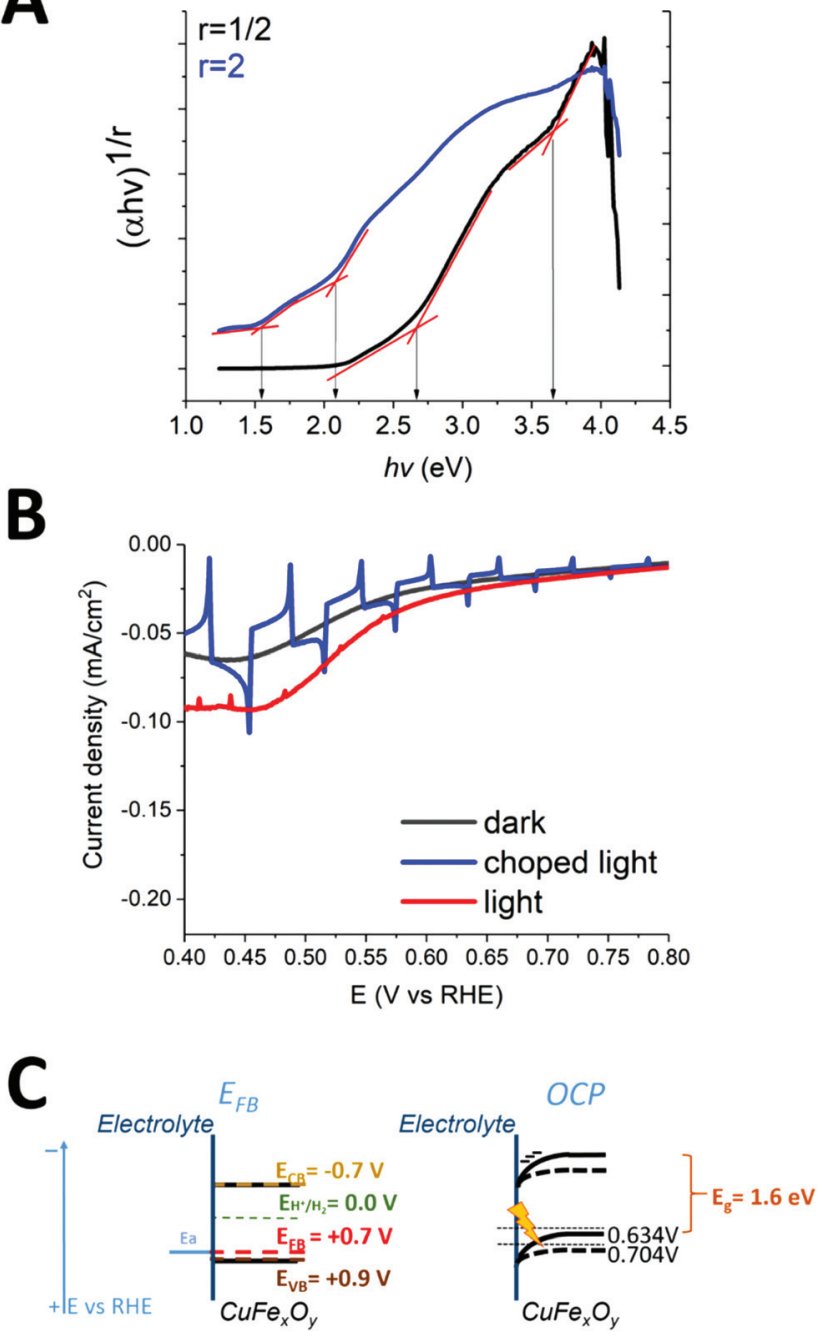

Fig. 4 (A) Tauc plots from CuFe $\mathrm{O}_{y \text { FLAT }}$ UV-visible spectrum for direct ( $r$ $\left.=\frac{1}{2}\right)$ and indirect $(r=2)$ bandgap calculation. (B) Linear sweep voltammogram (LSV) of $\mathrm{CuFe}_{x} \mathrm{O}_{y \text { STRUct }}$ films under chopped light irradiation (blue), constant irradiation (red) and in the dark (black) in $0.2 \mathrm{M}$ phosphate buffer $\mathrm{pH} 6.7$ at $10 \mathrm{mV} \mathrm{s}^{-1}$ scan rate, under argon; irradiation with 1 sun visible light (400-780 $\mathrm{nm}$ ). (C) Scheme of the energy bands of $\mathrm{CuFe}_{x} \mathrm{O}_{y \mathrm{FLAT}}$ films, where $E_{\mathrm{FB}}, E_{\mathrm{VB}}$ and $E_{\mathrm{CB}}$ are the flat-band, valence band and conduction band potentials, respectively, while $E_{\mathrm{H}+/ \mathrm{H}_{2}}$ is the redox potential corresponding to the proton reduction: left, the electrode is poised at the flat-band potential; right: the electrode is in equilibrium with the solution at the open circuit potential (OCP).

XRD spectrum of $\mathrm{CuFe}_{x} \mathrm{O}_{y \text { STRUCT }}$ samples revealed a higher ratio between $\mathrm{CuFe}_{2} \mathrm{O}_{4}$ and $\mathrm{CuFeO}_{2}$ phases. Nevertheless, $\mathrm{CuFe}_{2} \mathrm{O}_{4}$ has been also reported as a good candidate for HER under visible light, with a similar bandgap and band position as $\mathrm{CuFeO}_{2}$ delafossite. ${ }^{38,39}$

Bandgap energy values $\left(E_{\mathrm{g}}\right)$ for direct and indirect allowed transitions were determined by UV-visible absorbance spectrum. Tauc plots were measured based on the UV-visible absorbance data of $\mathrm{CuFe}_{x} \mathrm{O}_{y \text { FLAT }}$ corrected for FTO absorption and taking into account the thickness of the layers. As shown in Fig. 4A, CuFe $\mathrm{O}_{y \text { FLAT }}$ thin film exhibited an indirect bandgap 
of $1.6 \mathrm{eV}$ and two direct bandgaps of $2.65 \mathrm{eV}$ and $3.6 \mathrm{eV}$, in accordance to the literature for delafossite $\mathrm{CuFeO}_{2}{ }^{20,21,33}$ and spinel ferrite $\mathrm{CuFe}_{2} \mathrm{O}_{4}{ }^{39}$ confirming that this material is capable of absorbing visible light. However, an indirect bandgap at $2.0 \mathrm{eV}$ was also observed, confirming the presence of $\mathrm{Fe}_{2} \mathrm{O}_{3}$ parasitic phase (which bandgap is 2.0-2.2 eV) already observed by XRD. ${ }^{40}$

High resolution XPS analysis of $\mathrm{CuFe}_{x} \mathrm{O}_{y \text { struct }}$ revealed $\mathrm{Cu}(\mathrm{I})$ and $\mathrm{Cu}(\mathrm{II})$ oxidation states which suggests a mixture of delafossite $\mathrm{CuFeO}_{2}$ and ferrite $\mathrm{CuFe}_{2} \mathrm{O}_{4}$ phases, shown in Fig. S4. $\dagger$ The presence of $\mathrm{Cu}(\mathrm{II})$ is easily identified by intense peaks around $933 \mathrm{eV}$ together with satellite shake-up signals above $940 \mathrm{eV}$, while $\mathrm{Cu}(\mathrm{I})$ is evidenced by a single peak at $932 \mathrm{eV}$.

The flat band potential $\left(E_{\mathrm{FB}}\right)$ was determined through Mott-Schottky plot by performing EIS measurements. The p-type nature of the $\mathrm{CuFe}_{x} \mathrm{O}_{y}$ layers on FTO was confirmed by the negative slope of the Mott-Schottky plot. $E_{\mathrm{FB}}$ was estimated at $0.72 \mathrm{~V}$ vs. RHE in $0.2 \mathrm{M}$ phosphate buffer ( $\mathrm{pH} 6.7)$ and 10 $\mathrm{kHz}$ (Fig. S5 $\dagger$ ). ${ }^{41}$ This value is more negative than the already reported value of $1 \mathrm{~V} v s$. RHE for delafossite $\mathrm{CuFeO}_{2}{ }^{18}$ which again suggested the presence of impurities. The flat-band potential also corresponds to the potential at which the semiconductor starts to show photocurrents (onset potential) ${ }^{3}$ and a similar value of $E_{\mathrm{FB}} 0.70-0.75 \mathrm{~V} v s$. RHE is determined from LSV measurements on $\mathrm{CuFe}_{x} \mathrm{O}_{y \text { STRUCT }}$ back illuminated with 1 sun visible light $\left(65 \mathrm{~mW} \mathrm{~cm} \mathrm{~cm}^{-2}, 400-780 \mathrm{~nm}\right)$ in the same electrolyte (Fig. 4B). This electrolyte was selected based on previous studies on $\mathrm{Cu}$-based oxides conducted in neutral $\mathrm{pH} .{ }^{42,43}$ The open circuit potential (OCP) of the $\mathrm{CuFe}_{x} \mathrm{O}_{y}$ layers when illuminating the sample was $0.70 \mathrm{~V} v s$. RHE, and a shift in the photopotential towards less positive potential was recorded in dark (0.63 V vs. RHE), shown in Fig. S6. $\dagger$ When illuminating, the bands tended to flatten and the OCP became more positive. ${ }^{3}$ This behaviour also confirms the p-type nature of the semiconductor and its flat band potential measured by EIS. We acknowledge that OCP should be monitored for increasing light intensities until saturation is reached. Indeed if the light intensity is not high enough to flatten the bands, the flat band potential value may be underestimated. ${ }^{44}$ We note however that the OCP value measured under 1 sun illumination matches both onset photocurrent potential and $E_{\mathrm{FB}}$ value determined using Mott-Schottky analysis.

When potentials more negative than the onset potential are applied to the $\mathrm{CuFe}_{x} \mathrm{O}_{y \text { struct }}$ electrodes, the energy bands at the surface of the semiconductor in contact with the electrolyte bend towards more negative potential allowing electrons to travel to the electrolyte. According to the reported data, ${ }^{18}$ the diffusion length of the charge carriers of $\mathrm{CuFeO}_{2}$ delafossite is $\approx 300 \mathrm{~nm}$. Therefore, the thickness of the $\mathrm{CuFe}_{x} \mathrm{O}_{y}$ layers was convenient to allow both the electrons from the hole-electron pair created near the interface with the FTO and the holes created at the surface with the electrolyte to reach the electrolyte and the FTO back contact, respectively, before they recombine. Indeed, LSV measured for $\mathrm{CuFe}_{x} \mathrm{O}_{y \text { struct }}$ electrodes displayed cathodic photocurrents (Fig. 4B) under visible light irradiation. At $0.4 \mathrm{~V}$ vs. RHE photocurrent density reached
$85 \mu \mathrm{A} \mathrm{cm} \mathrm{cm}^{-2}$ (Fig. 4B) which is close to the performances reported for similar delafossite $\mathrm{CuFeO}_{2}$ samples in the absence of other electron acceptor apart from protons. ${ }^{45}$

The energy bands position of the $\mathrm{CuFe}_{x} \mathrm{O}_{y}$ layers and its behaviour in equilibrium with the electrolyte are represented in Fig. 4C. Assuming that the valence band is located $0.1-0.2 \mathrm{~V}$ below the flatband potential $\left(E_{\mathrm{FB}}=+0.7 \mathrm{~V} v s\right.$. RHE), ${ }^{46}$ we determined $E_{\mathrm{VB}}=+0.8$ to $+0.9 \mathrm{~V} v s$. RHE. Considering the indirect band gap $\left(E_{\mathrm{g}}\right)$ of $1.6 \mathrm{eV}$, the conduction band is therefore placed at -0.7 to $-0.8 \mathrm{~V}$ vs. $\mathrm{RHE}\left(E_{\mathrm{CB}}=E_{\mathrm{VB}}-E_{\mathrm{g}}\right)$. Therefore, the conduction band is negative enough for protons reduction, as illustrated in the scheme in Fig. 4C.

\section{Catalyst grafting and photoelectrochemical performance for HER}

The CoHEC catalyst is a cobaloxime bearing an axial $4,4^{\prime}$-pyridine ligand functionalized with two carboxylic acid anchoring groups. Following its use in dye-sensitized photoelectrodes, ${ }^{25,28}$ it was selected as a candidate to enhance the efficiency of the photoelectrocatalytic proton reduction at the surface of the $\mathrm{CuFe}_{x} \mathrm{O}_{y}$ electrodes. The grafting of CoHEC on $\mathrm{CuFe}_{x} \mathrm{O}_{y \text { STRUCT }}$ electrode was achieved by soaking $\mathrm{CuFe}_{x} \mathrm{O}_{y \text { STRUCT }}$ electrodes in a methanolic CoHEC $(0.7 \mathrm{mM})$ solution overnight. The presence of CoHEC grafted on $\mathrm{CuFe}_{x} \mathrm{O}_{y}$ was evidenced by the increase in the absorbance around 450-350 $\mathrm{nm}$ in the UV-visible absorption spectrum (Fig. S7 $\dagger$ ), as previously reported. ${ }^{47}$ The presence of cobalt in the $\mathrm{CuFe}_{x} \mathrm{O}_{y \text { STRUCT }}$-CoHEC samples was confirmed by ICP with Co emission observed at $228.616 \mathrm{eV}$ (Fig. S8†). The ICP signal is within the detection limit of this technique, indicating a

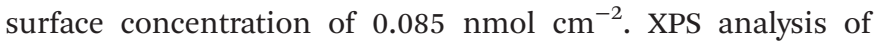
$\mathrm{CuFe}_{x} \mathrm{O}_{y \text { STRUCT }}$-CoHEC showed characteristic peaks of $\mathrm{Co}$ (II) $2 \mathrm{p}_{3 / 2}$ with a multiplet splitting due to the coupling with the unpaired electrons and plasmon losses (779.9, 782.3, and $787.7 \mathrm{eV}$ ) likely corresponding to a single Co complex, ${ }^{48}$ and two nitrogen atoms ( $\mathrm{N}$ 1s at $399.0 \mathrm{eV}$ for pyridinic $\mathrm{N}$ and 401.1 $\mathrm{eV}$ for oxime $\mathrm{N}$ ), confirming the presence of the cobalt center of the CoHEC as well as nitrogen present in CoHEC ligands (Fig. S9†). Co: $\mathrm{N}$ ratio obtained from the XPS studies is 6.3, which is very close to 6 expected from the stoichiometry of the complex.

Catalytic onset potential for hydrogen evolution mediated by CoHEC at a bare FTO electrode in the dark was measured at $-0.26 \mathrm{~V}$ vs. RHE in $0.2 \mathrm{M}$ phosphate buffer ( $\mathrm{pH}$ 6.7) (Fig. 5 and $\mathrm{S} 10 \dagger)$, in accordance to the values reported in neutral $\mathrm{pH} .{ }^{25}$ Sensitization with $\mathrm{CuFe}_{x} \mathrm{O}_{y \text { STRUCT }}$ shifts this onset potential to $+0.7 \mathrm{~V} v s$. RHE, in accordance to the $E_{\mathrm{FB}}$ value previously determined for $\mathrm{CuFe}_{x} \mathrm{O}_{y}$ films. In other words, the $\mathrm{CuFe}_{x} \mathrm{O}_{y \text { STRUCT }}$ material provides a photovoltage of $\sim 960 \mathrm{mV}$ to the $\mathrm{H}_{2}$ evolution reaction, which is definitely much higher than that provided by $\mathrm{p}-\mathrm{Si}$ or $\mathrm{Cu}_{2} \mathrm{O}$. Indeed, the onset potentials reported for $\mathrm{p}-\mathrm{Si},{ }^{23,49} \mathrm{Cu}_{2} \mathrm{O}^{6}$ or $\mathrm{WSe}_{2}{ }^{50}$ photocathodes are 0.4-0.6 V vs. RHE. As shown in Fig. 5 and Fig. S11, $\dagger$ photocurrents measured at $\mathrm{CuFe}_{x} \mathrm{O}_{y \text { STRUCT }}$-CoHEC are twice higher than those measured at unfunctionalized $\mathrm{CuFe}_{x} \mathrm{O}_{y \text { struct }}$ photocathodes in the absence of CoHEC, showing the benefit of 


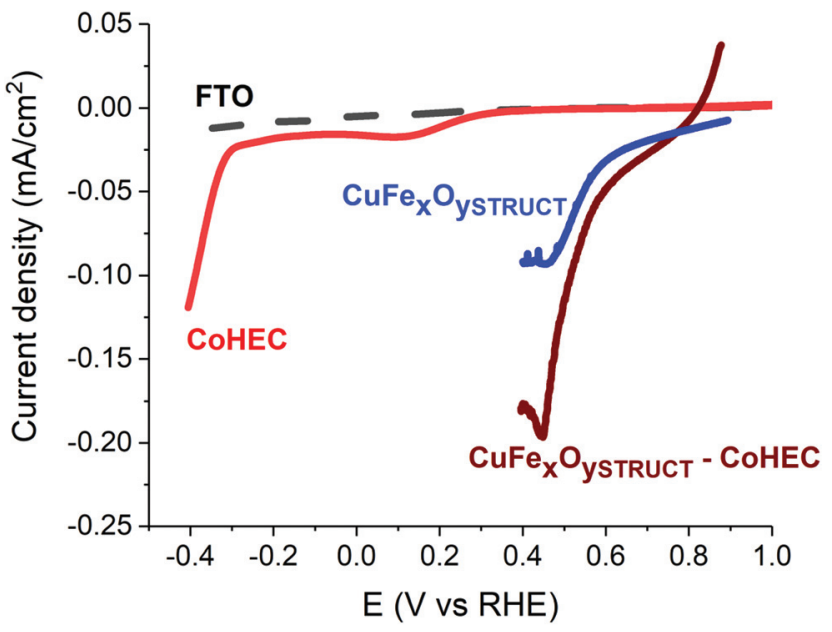

Fig. 5 LSV for bare FTO substrate (dashed line in black), bare FTO substrate with $0.7 \mathrm{mM} \mathrm{CoHEC}$ in solution (straight red line), CuFe $\mathrm{O}_{y \text { STRUCT }}$ modified FTO substrate (straight blue line) and $\mathrm{CuFe}_{x} \mathrm{O}_{y \text { STRUCT }}$ decorated with COHEC (straight brown line). Irradiation of 1 sun visible light $(400-780 \mathrm{~nm})$ in $0.2 \mathrm{M}$ phosphate buffer $(\mathrm{pH} 6.7)$ at $10 \mathrm{mV} \mathrm{s}^{-1}$ scan rate under nitrogen.

surface functionalization to enhance charge extraction and catalysis.

Such an improvement was confirmed during chronoamperometric measurements performed at $0.4 \mathrm{~V}$ vs. RHE under irradiation (Fig. 6A). The photocurrent for $\mathrm{CuFe}_{x} \mathrm{O}_{y \text { STRUCT }}$ photocathode reached just $-14 \mu \mathrm{A} \mathrm{cm} \mathrm{cm}^{-2}$. However, when CoHEC was grafted on the surface of $\mathrm{CuFe}_{x} \mathrm{O}_{y \text { STRUCT }}$, photocurrents were up to 4 times higher, varying from -60 to $-20 \mu \mathrm{A}$ $\mathrm{cm}^{-2}$ during the first minute and remaining higher than those measured at $\mathrm{CuFe}_{x} \mathrm{O}_{y \text { STRUCT }}$ photocathode during the first 8 min.

The amount of hydrogen produced in solution was measured with an hydrogen probe, calibrated following the procedure described in previous publication. ${ }^{35}$ The calculated faradaic yields (FY) for both $\mathrm{CuFe}_{x} \mathrm{O}_{y \text { StRUCT }}$ and $\mathrm{CuFe}_{x} \mathrm{O}_{y \text { STRUCT-CoHEC after }} 20$ min were $2 \%$ and $6 \%$, respecti-
Table 1 Hydrogen production, FY, TON and TOF values for $\mathrm{CuFe}_{x} \mathrm{O}_{y \text { StRuct, }}, \mathrm{CuFe}_{x} \mathrm{O}_{y \text { STRUct }}-\mathrm{CoHEC}, \mathrm{CuFe}_{x} \mathrm{O}_{y} \mid \mathrm{TiO}_{2}$ and $\mathrm{CuFe}_{x} \mathrm{O}_{y} \mid$ $\mathrm{TiO}_{2}$-CoHEC photocathodes. $0.2 \mathrm{M}$ phosphate buffer (pH 6.7), 1 sun irradiation ( $65 \mathrm{~mW} \mathrm{~cm}^{-2}, 400-700 \mathrm{~nm}$ ), at $0.4 \mathrm{~V}$ vs. RHE applied bias for $20 \mathrm{~min}$

\begin{tabular}{|c|c|c|c|c|c|}
\hline Electrode & $\begin{array}{l}Q \\
\left(\mathrm{mC} \mathrm{cm}^{-2}\right)\end{array}$ & $\begin{array}{l}\mathrm{H}_{2} \\
\left(\mathrm{nmol} \mathrm{cm}^{-2}\right)\end{array}$ & $\begin{array}{l}\text { FY } \\
(\%)\end{array}$ & $\mathrm{TON}_{\mathrm{Co}}$ & $\begin{array}{l}\text { Average } \\
\text { TOF } \\
\left(\mathrm{s}^{-1}\right)\end{array}$ \\
\hline $\mathrm{CuFe}_{x} \mathrm{O}_{y \text { STRUCT }}$ & $70 \pm 30$ & $4.8 \pm 2$ & 2 & & \\
\hline $\mathrm{CuFe}_{x} \mathrm{O}_{y \text { STRUCT }}$-CoHEC & $16 \pm 7$ & $4.8 \pm 2$ & 6 & $57 \pm 30$ & 0.05 \\
\hline $\mathrm{CuFe}_{x} \mathrm{O}_{y} \mid \mathrm{TiO}_{2}$ & $4 \pm 1$ & $4.3 \pm 1$ & 22 & & \\
\hline $\mathrm{CuFe}_{x} \mathrm{O}_{y} \mid \mathrm{TiO}_{2}$-CoHEC & $3 \pm 1$ & $7.6 \pm 2$ & 54 & $90 \pm 30$ & 0.08 \\
\hline
\end{tabular}

vetely (Table 1). Based on the estimated Co surface concentration, the turnover number (TON) was $57 \pm 30$ for $\mathrm{CuFe}_{x} \mathrm{O}_{y^{-}}$ CoHEC, corresponding to an average turnover frequency (TOF) of $0.05 \mathrm{~s}^{-1}$. However, longer chronoamperometries did not result in higher amount of hydrogen produced. These results clearly show that the efficiency of catalytic hydrogen production is enhanced with CoHEC grafted on the surface of $\mathrm{CuFe}_{x} \mathrm{O}_{y}$. However, desorption of the catalyst occurred within minutes of operation as shown in Fig. 6A. The photocurrent decreased along time in the case of $\mathrm{CuFe}_{x} \mathrm{O}_{y}$-CoHEC, reaching the values similar to $\mathrm{CuFe}_{x} \mathrm{O}_{\mathrm{ySTRUCT}}$ after 8 minutes, and even lower photocurrents afterwards, indicating some degradation of the photocathode materials. Partial loss of cobalt from the surface is confirmed by ICP (Fig. S8†) and XPS (Fig. S9†) measurements after $20 \mathrm{~min}$ chronoamperometric measurement. For example, the $\mathrm{Co}: \mathrm{Cu}$ surface atomic ratio drops from initial 3.7 to 0.14 . It is also consistent with a former observation made for similar cobaloxime catalysts immobilized onto surfaces through axial pyridine ligand ${ }^{27,51}$ for cathodes operated in the dark and for CoHEC grafted onto dye-sensitized NiO. ${ }^{25}$ The CoHEC grafting did not affect apparently the $\mathrm{CuFe}_{x} \mathrm{O}_{y \text { struct }}$ composition, since the observed $\mathrm{Cu} 2 \mathrm{p}$ and $\mathrm{Fe} 2 \mathrm{p}$ XPS peaks are similar for both samples (Fig. S4 $\dagger$ ). However, after applying bias potential to the sample in presence of grafted CoHEC, the Cu visible by XPS was almost completely
1

B

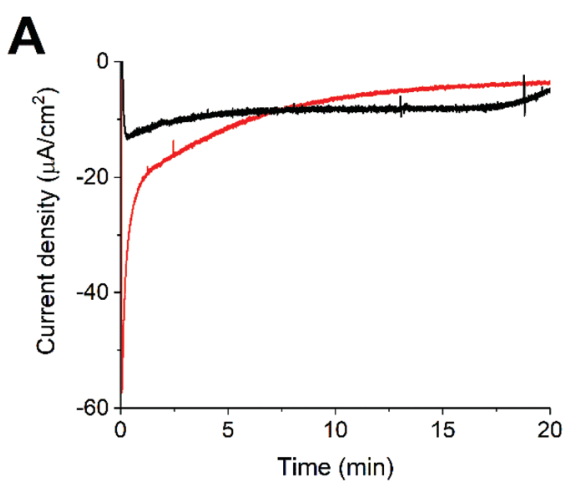

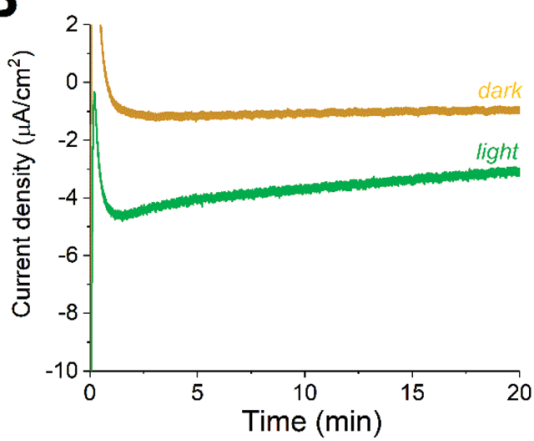

Fig. 6 (A) Chronoamperometries at $+0.4 \mathrm{~V}$ vs. RHE on $\mathrm{CuFe}_{x} \mathrm{O}_{y \text { STRUCT }}$ (black) and $\mathrm{CuFe}_{x} \mathrm{O}_{y \text { STRUCT }}$-CoHEC (red) photoelectrodes, irradiated by 1 sun visible light $\left(400-780 \mathrm{~nm}\right.$ ) under nitrogen. (B) Chronoamperometries at $0.4 \mathrm{~V}$ vs. $\mathrm{RHE}$ on $\mathrm{CuFe}_{x} \mathrm{O}_{y} \mid \mathrm{TiO}_{2}-\mathrm{CoHEC}$ under dark (brown) and light (green) conditions. Measurements in $0.2 \mathrm{M}$ phosphate buffer ( $\mathrm{pH}$ 6.7). 
1 reduced to $\mathrm{Cu}(\mathrm{I})$, which can explain the limited faradaic efficiency for $\mathrm{H}_{2}$ evolution. This reduction phenomenon does not occur in the absence of CoHEC grafting but we observed a significant modification of the $\mathrm{CuFe}_{x} \mathrm{O}_{y}$ material upon turnover. Indeed, the $\mathrm{Cu}: \mathrm{Fe}$ atomic ratio measured by EDX changed from 1:1.3 before electrochemical treatment to $1: 5$ after treatment, indicating a significant loss of copper during operation (Fig. S12 $\dagger$ ). The degradation of the surface of the $\mathrm{CuFe}_{x} \mathrm{O}_{y \text { STRUCT }}$ electrode was confirmed by SEM (Fig. S13 $\dagger$ ). XRD performed on $\mathrm{CuFe}_{x} \mathrm{O}_{y \text { STRUCT }}$ electrodes after treatment revealed new unknown peaks which correspond neither to $\mathrm{CuFe}_{2} \mathrm{O}_{4}, \mathrm{CuFeO}_{2}, \mathrm{Cu}_{2} \mathrm{O}$ nor to $\mathrm{Fe}_{2} \mathrm{O}_{3}$ (Fig. $\mathrm{S} 14 \dagger$ ). To overcome such a degradation, we decided to protect the $\mathrm{CuFe}_{x} \mathrm{O}_{y}$ material by depositing a thin $\mathrm{TiO}_{2}$ layer on top.

\section{Optimisation through atomic layer deposition of $\mathrm{TiO}_{2}$}

The instability of semiconductors under photoelectrochemical conditions is a general problem that can be solved by deposition of metal oxides protecting ${ }^{23,52,53}$ or passivating layers. ${ }^{54}$ A classical protection strategy is the deposition of a few $\mathrm{nm}$ of thin amorphous $\mathrm{TiO}_{2}$ layer by atomic layer deposition (ALD), 23,26,49,55,56 allowing to control the thickness and improve the homogeneity of the surface layer.

We therefore deposited an amorphous $\mathrm{TiO}_{2}$ layer, with a $8.3 \mathrm{~nm}$ thickness measured by ellipsometry (Fig. S15†), onto a flat $\mathrm{CuFe}_{x} \mathrm{O}_{y}$ film by ALD following the procedure reported elsewhere. ${ }^{23}$ Fig. 3Ae shows the top view of amorphous $\mathrm{TiO}_{2}$ deposited on $\mathrm{CuFe}_{x} \mathrm{O}_{y \mathrm{FLAT}}$ electrode, revealing nanostructured $\mathrm{TiO}_{2}$. It has been previously shown that a $\sim 10 \mathrm{~nm}$ layer of amorphous $\mathrm{TiO}_{2}$ is thick enough to passivate a semiconductor. ${ }^{56}$ Since the resistance increases and the photoelectrochemical response drops with the thickness of the $\mathrm{TiO}_{2}$ layer, ${ }^{56}$ we limited the ALD process on $\mathrm{CuFe}_{x} \mathrm{O}_{y \text { FLAT }}$ to 355 cycles, corresponding to a thickness of $8.3 \mathrm{~nm}$ measured by ellipsometry.

XRD was performed on $\mathrm{CuFe}_{x} \mathrm{O}_{y} \mid \mathrm{TiO}_{2}$ electrodes. The main phase was $\mathrm{CuFe}_{2} \mathrm{O}_{4}$ (Fig. S16†), indicating a structural change of the bulk materials during ALD deposition. No peaks corresponding to any crystalline phase of $\mathrm{TiO}_{2}$ were observed in the $\mathrm{CuFe}_{x} \mathrm{O}_{y} \mid \mathrm{TiO}_{2}$ electrodes diffractogram (Fig. S16 $\dagger$ ) confirming the amorphous character of the $\mathrm{TiO}_{2}$ layer, while the presence of Ti was confirmed by EDX (Fig. S17†) and XPS (Fig. S9B $\dagger$ ). LSV under choped light of $\mathrm{CuFe}_{x} \mathrm{O}_{y} \mid \mathrm{TiO}_{2}$-CoHEC is shown in Fig. S18, $\uparrow$ revealing lower photocurrent values and a shift of the onset photocurrent potential to $\sim 0.6 \mathrm{~V} v s$. RHE. This cathodic shift can be explained by the full oxidation of the $\mathrm{CuFe}_{x} \mathrm{O}_{y}$ material into $\mathrm{CuFe}_{2} \mathrm{O}_{4}$ during the ALD process. Although only approximate bandgap values can be determined for composite films, ${ }^{57}$ Tauc plots indicate higher $(2 \mathrm{eV})$ indirect bandgap for $\mathrm{CuFe}_{x} \mathrm{O}_{y} \mid \mathrm{TiO}_{2}$ layers compared to $\mathrm{CuFe}_{x} \mathrm{O}_{y}$ films (Fig. S19†), in line with the shift of the onset photocurrent potential.

CoHEC catalyst was grafted by immersing $\mathrm{CuFe}_{x} \mathrm{O}_{y} \mid \mathrm{TiO}_{2}$ electrodes in a methanolic solution of 0.7 M CoHEC overnight. The presence of CoHEC grafted on $\mathrm{CuFe}_{x} \mathrm{O}_{y}$ and $\mathrm{CuFe}_{x} \mathrm{O}_{y} \mid \mathrm{TiO}_{2}$ was confirmed by UV-visible spectroscopy (Fig. S7†). XPS analysis of the latter reveals a Co species manifested as three $2 \mathrm{p}_{3 / 2}$ peaks at 781.8, 786.3, and $789.9 \mathrm{eV}$, while nitrogen $1 \mathrm{~s}$ appears poorly resolved at $400.3 \mathrm{eV}$ (Fig. S9†). Here again, the amount of cobalt catalyst was estimated by ICP at the detection limit of

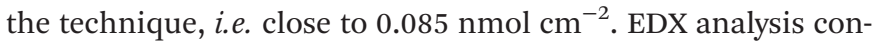
firmed the presence of $\mathrm{Ti}$ on the photoelectrode surface both before and after the photoelectrochemical experiment.

Photocurrents recorded for $\mathrm{CuFe}_{x} \mathrm{O}_{y} \mid \mathrm{TiO}_{2}$-CoHEC photocathodes proved to be more stable over time since no decrease in the photocurrent was observed after 20 minutes (Fig. 6B). Within $20 \mathrm{~min}, \mathrm{CuFe}_{x} \mathrm{O}_{y} \mid \mathrm{TiO}_{2}$-CoHEC photocathodes produced $7.6 \pm 2 \mathrm{nmol} \mathrm{H}_{2}$ per $\mathrm{cm}^{2}$ with $54 \%$ FY. A control experiment of $\mathrm{CuFe}_{x} \mathrm{O}_{y} \mid \mathrm{TiO}_{2}$ in the absence of the CoHEC catalyst was launched recording $4.3 \pm 1 \mathrm{nmol} \mathrm{H}_{2}$ per $\mathrm{cm}^{2}$ and $22 \% \mathrm{FY}$. The TON based on estimated Co surface concentration was $90 \pm 30$ for $\mathrm{CuFe}_{x} \mathrm{O}_{y} \mid \mathrm{TiO}_{2}-\mathrm{CoHEC}$. The TOFs for $\mathrm{CuFe}_{x} \mathrm{O}_{y} \mid \mathrm{TiO}_{2}-\mathrm{CoHEC}$ were estimated to $0.08 \mathrm{~s}^{-1}$. All these values are summarized in Table 1.

Additional measurements were carried out under the same conditions but with slightly higher visible-light intensity (up to $\left.100 \mathrm{~mW} \mathrm{~cm}{ }^{-2} ; 1.3 \mathrm{sun}\right) . \mathrm{CuFe}_{x} \mathrm{O}_{y \text { StRuct }}$ and $\mathrm{CuFe}_{x} \mathrm{O}_{y \text { STRUCT }^{-}}$ CoHEC displayed $3 \%$ and $6 \%$ FY respectively, with similar behaviour regarding the desorption of catalyst and poor stability (Fig. S20 $\dagger$ ). However, under these conditions, the protected $\mathrm{CuFe}_{x} \mathrm{O}_{y} \mid \mathrm{TiO}_{2}$-CoHEC photocathode showed $88 \% \mathrm{FY}$ and 90 TON achieved within $20 \mathrm{~min}$.

The hybrid photocathodes were evaluated up to two hours without increase in the amount of hydrogen detected, suggesting the photocathodes lost their activity following desorption of the catalyst which was already confirmed by the absence of peaks in the ICP and XPS measurements after 20 min CA (Fig. S8 and S9†).

Clearly, the presence of $\mathrm{TiO}_{2}$ significantly and positively affects the $\mathrm{FY}$ for $\mathrm{H}_{2}$ evolution. Although the photocurrent values are significantly lower for $\mathrm{TiO}_{2}$-protected photoelectrodes, the amount of hydrogen produced remains similar $\left(4.8 \mathrm{nmol} \mathrm{cm}^{-2}\right.$ for $\mathrm{CuFe}_{x} \mathrm{O}_{y}$ and $4.3 \mathrm{nmol} \mathrm{cm}^{-2}$ for $\mathrm{CuFe}_{x} \mathrm{O}_{y}$ । $\mathrm{TiO}_{2}$ ) or largely enhanced $\left(4.8 \mathrm{nmol} \mathrm{cm}{ }^{-2}\right.$ for $\mathrm{CuFe}_{x} \mathrm{O}_{y \text { STRUCT }^{-}}$ CoHEC and $7.6 \mathrm{nmol} \mathrm{cm}{ }^{-2}$ for $\left.\mathrm{CuFe}_{x} \mathrm{O}_{y} \mid \mathrm{TiO}_{2}-\mathrm{CoHEC}\right)$. This indicates that $\mathrm{TiO}_{2}$ has no significant effect in the catalysis for hydrogen evolution but that it prevents at least partially the photocorrosion of the semiconductor. The protected photocathodes showed an average $\mathrm{Cu}:$ Fe ratio of $1: 1.8$, unchanged after photoelectrochemical measurement. Any modification in the phase of the material was not observed by XRD after chronoamperometry (Fig. S11†). Additionally, the presence of $\mathrm{TiO}_{2}$ significantly limits the decrease in the photocurrent intensity over time, indicating a better stability of the anchoring of the carboxylate functions of CoHEC onto $\mathrm{TiO}_{2}$ compared to $\mathrm{CuFe}_{x} \mathrm{O}_{y}$.

When compared with other hybrid photocathodes from the literature, i.e. the $\mathrm{p}$-GaInP $\mathrm{P}_{2} / \mathrm{TiO}_{2}$-cobaloxime architecture described by Turner et al. $(100 \% \mathrm{FY}, \mathrm{TON}=1400000),{ }^{26} \mathrm{p}-\mathrm{Si} /$ mesoTiO 2 -NiP system described by Reisner $(80 \% \mathrm{FY}$, TON = $646)^{49}$ and the $\mathrm{p}-\mathrm{Si} / \mathrm{mesoTiO}_{2}-\mathrm{Co}_{\mathrm{C} 11 \mathrm{P}}$ photocathode reported recently by us $(>80 \% \mathrm{FY}$, TON $>200),{ }^{23}$ the performance of the hybrid $\mathrm{CuFe}_{x} \mathrm{O}_{y} \mid \mathrm{TiO}_{2}$-CoHEC $(54-88 \%$ FY, TON = 90) may 
appear limited. However, previous litterature data were measured at an applied potential of $0-0.1 \mathrm{~V} v s$. RHE, i.e. with a much larger driving force compared to data reported here, which were measured at $0.4 \mathrm{~V}$ vs. RHE. Besides stability and selectivity, important metrics for the photocathode performances are indeed its onset photopotential and the maximum photocurrent density. While $\mathrm{p}$-Si and $\mathrm{Cu}_{2} \mathrm{O}$-based photocathodes display limited onset photocurrent potentials $(<0.4 \mathrm{~V}$ vs. $\mathrm{RHE}$ ), the $\mathrm{CuFe}_{x} \mathrm{O}_{y}$-based ones reported here perform better with $0.7 \mathrm{~V} v s$. RHE onset photocurrent potential. Although not as efficient as those displayed by $\mathrm{WSe}_{2}{ }^{58}$ or $\left(\mathrm{CuGa}_{1-y} \mathrm{In}_{y}\right)_{1-x} \mathrm{Zn}_{2 x} \mathrm{~S}_{2}{ }^{59}$ photocathodes, such a positive value vs. RHE compares well with the onset photocurent potentials of dye-sensitized $\mathrm{NiO}^{35,60-62}$ and $\mathrm{CuCrO}_{2}{ }^{63}$ or $\mathrm{CuGaO}_{2}{ }^{25}$ photocathodes. However, the maximum photocurrent reported here is already one order of magnitude higher compared to dye-sensitized molecular photocathodes and there is still room for improvement through the composition optimization and nanostructuration. The cost and scalability of $\mathrm{CuFe}_{x} \mathrm{O}_{y}$ materials are similar to those of the above mentioned transparent semiconducting oxides, while there is no need to sensitize them as they naturally absorb in the visible region. Compared with expensive III-V semiconductors such as InP, $\mathrm{GaP}$ or $\mathrm{GaInP}_{2}$, such ternary oxide-based semiconductors therefore prove promising for implementation in photoelectrochemical cells. $^{7,25,27,64}$

\section{Conclusion}

We successfully designed a hybrid photocathode for $\mathrm{H}_{2}$ evolution exclusively based on Earth-abundant elements. $300 \mathrm{~nm}$ thick $\mathrm{CuFe}_{x} \mathrm{O}_{y}$ films indeed behave as a visible light absorber, perform charge separation and transport electron to the interface with the electrolyte where molecular catalyst can be positioned, for $\mathrm{H}_{2}$ evolution to occur at a potential $860 \mathrm{mV}$ more positive compared to the dark conditions. Atomic layer deposition of amorphous $\mathrm{TiO}_{2}$ layer on top of the $\mathrm{CuFe}_{x} \mathrm{O}_{y}$ film enhances the efficiency and improves the stability of the photoelectrode. Nevertheless, the stability of $\mathrm{CuFe}_{x} \mathrm{O}_{y}$ material remains challenging and must be further improved for PEC applications, calling for a better understanding of the modifications of $\mathrm{CuFe}_{x} \mathrm{O}_{y}$ films upon heat, irradiation or electrochemical treatment.

\section{Conflicts of interest}

\section{Acknowledgements}

This work is supported by the CEA DRF Impulsion 2018 and the Make Our Planet Great Again (MOPGA) programs, as well as the Agence Nationale de la Recherche (Labex ARCANE, CBH-EUR-GS, ANR-17-EURE-0003). We acknowledge Adina
Morozan for her help regarding the characterization of the $\mathrm{CuFe}_{x} \mathrm{O}_{y}$ films.

\section{References}

1 O. Kraan, G. J. Kramer, M. Haigh and C. Laurens, Joule, 2019, 3, 2286-2290.

2 S. Ardo, D. F. Rivas, M. A. Modestino, V. S. Greiving, F. F. Abdi, E. A. Llado, V. Artero, K. Ayers, C. Battaglia, J.-P. Becker, D. Bederak, A. Berger, F. Buda, E. Chinello, B. Dam, V. D. Palma, T. Edvinsson, K. Fujii, H. Gardeniers, H. Geerlings, S. M. H. Hashemi, S. Haussener, F. Houle, J. Huskens, B. D. James, K. Konrad, A. Kudo, P. Patil Kunturu, D. Lohse, B. Mei, E. L. Miller, G. F. Moore, J. Muller, K. L. Orchard, T. E. Rosser, F. H. Saadi, J.-W. Schüttauf, B. Seger, S. W. Sheehan, W. A. Smith, J. Spurgeon, M. H. Tang, R. van de Krol, P. C. K. Vesborg and P. Westerik, Energy Environ. Sci., 2018, 11, 2768-2783.

3 R. van de Krol and M. Gratzel, Photoelectrochemical Hydrogen Production, Springer US, 2012, vol. 102.

4 L. Pan, N. Vlachopoulos and A. Hagfeldt, ChemSusChem, 2019, 12, 4337-4352.

5 X. Li, B. Liu, Y. Chen, X. Fan, Y. Li, F. Zhang, G. Zhang and W. Peng, Nanotechnology, 2018, 29, 505603.

6 H. Qi, J. Wolfe, D. Fichou and Z. Chen, Sci. Rep., 2016, 6, 30882.

7 A. Paracchino, V. Laporte, K. Sivula, M. Grätzel and E. Thimsen, Nat. Mater., 2011, 10, 456.

8 L. Pan, Y. Liu, L. Yao, D. Ren, K. Sivula, M. Grätzel and A. Hagfeldt, Nat. Commun., 2020, 11, 318.

9 Y.-H. Lai, H. S. Park, J. Z. Zhang, P. D. Matthews, D. S. Wright and E. Reisner, Chem. - Eur. J., 2015, 21, 39193923.

10 J. D. Benck, S. C. Lee, K. D. Fong, J. Kibsgaard, R. Sinclair and T. F. Jaramillo, Adv. Energy Mater., 2014, 4, 1400739.

11 M. Lancaster, R. Mow, J. Liu, Q. Cheek, M. M. MacInnes, M. M. Al-Jassim, T. G. Deutsch, J. L. Young and S. Maldonado, ACS Appl. Mater. Interfaces, 2019, 11, 2511525122.

12 B. Kim, G.-S. Park, S. Y. Chae, M. K. Kim, H.-S. Oh, Y. J. Hwang, W. Kim and B. K. Min, Sci. Rep., 2018, 8, 1-10.

13 R. Fan, J. Mao, Z. Yin, J. Jie, W. Dong, L. Fang, F. Zheng and M. Shen, ACS Appl. Mater. Interfaces, 2017, 9, 61236129.

14 D. Cedeno, A. Krawicz, P. Doak, M. Yu, J. B. Neaton and G. F. Moore, J. Phys. Chem. Lett., 2014, 5, 3222-3226.

15 A. Krawicz, D. Cedeno and G. F. Moore, Phys. Chem. Chem. Phys., 2014, 16, 15818-15824.

16 K. Sekizawa, K. Oh-ishi, K. Kataoka, T. Arai, T. M. Suzuki and T. Morikawa, J. Mater. Chem. A, 2017, 5, 6483-6493.

17 K. Rajeshwar, M. K. Hossain, R. T. Macaluso, C. Janáky, A. Varga and P. J. Kulesza, J. Electrochem. Soc., 2018, 165, H3192-H3206.

0


18 M. S. Prévot, X. A. Jeanbourquin, W. S. Bourée, F. Abdi, D. Friedrich, R. van de Krol, N. Guijarro, F. Le Formal and K. Sivula, Chem. Mater., 2017, 29, 4952-4962.

19 H.-Y. Chen and J.-H. Wu, Appl. Surf. Sci., 2012, 258, 48444847.

20 C. G. Read, Y. Park and K.-S. Choi, J. Phys. Chem. Lett., 2012, 3, 1872-1876.

21 Y. J. Jang, Y. B. Park, H. E. Kim, Y. H. Choi, S. H. Choi and J. S. Lee, Chem. Mater., 2016, 28, 6054-6061.

22 N. Kaeffer, M. Chavarot-Kerlidou and V. Artero, Acc. Chem. Res., 2015, 48, 1286-1295.

23 S. Chandrasekaran, N. Kaeffer, L. Cagnon, D. Aldakov, J. Fize, G. Nonglaton, F. Baleras, P. Mailley and V. Artero, Chem. Sci., 2019, 10, 4469-4475.

24 N. M. Muresan, J. Willkomm, D. Mersch, Y. Vaynzof and E. Reisner, Angew. Chem., Int. Ed., 2012, 51, 12749-12753.

25 C. D. Windle, H. Kumagai, M. Higashi, R. Brisse, S. Bold, B. Jousselme, M. Chavarot-Kerlidou, K. Maeda, R. Abe, O. Ishitani and V. Artero, J. Am. Chem. Soc., 2019, 141, 9593-9602.

26 J. Gu, Y. Yan, J. L. Young, K. X. Steirer, N. R. Neale and J. A. Turner, Nat. Mater., 2015, 15, 456.

27 S. Donck, J. Fize, E. Gravel, E. Doris and V. Artero, Chem. Commun., 2016, 52, 11783-11786.

28 K. Fan, F. Li, L. Wang, Q. Daniel, E. Gabrielsson and L. Sun, Phys. Chem. Chem. Phys., 2014, 16, 25234-25240.

29 F. Li, K. Fan, B. Xu, E. Gabrielsson, Q. Daniel, L. Li and L. Sun, J. Am. Chem. Soc., 2015, 137, 9153-9159.

30 M. Wang, Y. Yang, J. Shen, J. Jiang and L. Sun, Sustainable Energy Fuels, 2017, 1, 1641-1663.

31 E. A. Gibson, Chem. Soc. Rev., 2017, 46, 6194-6209.

32 P. Xu, N. S. McCool and T. E. Mallouk, Nano Today, 2017, 14, 42-58.

33 H.-Y. Chen and G.-W. Fu, Appl. Surf. Sci., 2014, 288, 258264.

34 J. E. O’Reilly, Biochim. Biophys. Acta, Bioenerg., 1973, 292, 509-515.

35 C. D. Windle, J. Massin, M. Chavarot-Kerlidou and V. Artero, Dalton Trans., 2018, 47, 10509-10516.

36 B. Li, M. Li, C. Yao, Y. Shi, D. Ye, J. Wu and D. Zhao, J. Mater. Chem. A, 2013, 1, 6742-6749.

37 M. J. (韩美杰) Han, Z. H. (段志华) Duan, J. Z. (张金中) Zhang, S. (张思) Zhang, Y. W. (李亚巍) Li, Z. G. (胡志高) Hu and J. H. (褚君浩) Chu, J. Appl. Phys., 2013, 114, 163526.

38 H. Yang, J. Yan, Z. Lu, X. Cheng and Y. Tang, J. Alloys Compd., 2009, 476, 715-719.

39 S. Park, J. H. Baek, L. Zhang, J. M. Lee, K. H. Stone, I. S. Cho, J. Guo, H. S. Jung and X. Zheng, ACS Sustainable Chem. Eng., 2019, 7, 5867-5874.

40 R. L. Spray and K.-S. Choi, Chem. Mater., 2009, 21, 37013709.

41 W. P. Gomes and D. Vanmaekelbergh, Electrochim. Acta, 1996, 41, 967-973.

42 F. Wang, W. Septina, A. Chemseddine, F. F. Abdi, D. Friedrich, P. Bogdanoff, R. van de Krol, S. D. Tilley and S. P. Berglund, J. Am. Chem. Soc., 2017, 139, 15094-15103.
43 S. P. Berglund, F. F. Abdi, P. Bogdanoff, A. Chemseddine, D. Friedrich and R. van de Krol, Chem. Mater., 2016, 28, 4231-4242.

44 Z. Chen, Photoelectrochemical Water Splitting - Standards, Experimental Methods, and Protocols, Springer.

45 M. S. Prévot, N. Guijarro and K. Sivula, ChemSusChem, 2015, 8, 1359-1367.

46 S. R. Morrison, Electrochemistry at Semiconductor and Oxidized Metal Electrodes, Springer, 1980.

47 J. Huang, Y. Tang, K. L. Mulfort and X. Zhang, Phys. Chem. Chem. Phys., 2016, 18, 4300-4303.

48 M. C. Biesinger, B. P. Payne, A. P. Grosvenor, L. W. M. Lau, A. R. Gerson and R. St. C. Smart, Appl. Surf. Sci., 2011, 257, 2717-2730.

49 J. J. Leung, J. Warnan, D. H. Nam, J. Z. Zhang, J. Willkomm and E. Reisner, Chem. Sci., 2017, 8, 5172-5180.

50 J. R. McKone, A. P. Pieterick, H. B. Gray and N. S. Lewis, J. Am. Chem. Soc., 2013, 135, 223-231.

51 B. Reuillard, J. Warnan, J. J. Leung, D. W. Wakerley and E. Reisner, Angew. Chem., Int. Ed., 2016, 55, 3952-3957.

52 J. Toupin, H. Strub, S. Kressmann, M. Boudot, V. Artero and C. Laberty-Robert, Phys. Chem. Chem. Phys., 2017, 19, 30675-30682.

53 C. G. Morales-Guio, L. Liardet, M. T. Mayer, S. D. Tilley, M. Grätzel and X. Hu, Angew. Chem., Int. Ed., 2014.

54 I. V. Bagal, N. R. Chodankar, M. A. Hassan, A. Waseem, M. AliJohar, D.-H. Kim and S.-W. Ryu, Int. J. Hydrogen Energy, 2019, 44, 21351-21378.

$55 \mathrm{~S} . \mathrm{Hu}, \mathrm{M}$. R. Shaner, J. A. Beardslee, M. Lichterman, B. S. Brunschwig and N. S. Lewis, Science, 2014, 344, 1005.

56 T. Moehl, J. Suh, L. Sévery, R. Wick-Joliat and S. D. Tilley, ACS Appl. Mater. Interfaces, 2017, 9, 43614-43622.

57 P. Makuła, M. Pacia and W. Macyk, J. Phys. Chem. Lett., 2018, 9, 6814-6817.

58 X. Yu, M. S. Prévot, N. Guijarro and K. Sivula, Nat. Commun., 2015, 6, 1-8.

59 T. Hayashi, R. Niishiro, H. Ishihara, M. Yamaguchi, Q. Jia, Y. Kuang, T. Higashi, A. Iwase, T. Minegishi, T. Yamada, K. Domen and A. Kudo, Sustainable Energy Fuels, 2018, 2, 2016-2024.

60 M. A. Gross, C. E. Creissen, K. L. Orchard and E. Reisner, Chem. Sci., 2016, 7, 5537-5546.

61 N. Kaeffer, C. D. Windle, R. Brisse, C. Gablin, D. Leonard, B. Jousselme, M. Chavarot-Kerlidou and V. Artero, Chem. Sci., 2018, 9, 6721-6738.

62 N. Kaeffer, J. Massin, C. Lebrun, O. Renault, M. ChavarotKerlidou and V. Artero, J. Am. Chem. Soc., 2016, 138, 1230812311.

63 C. E. Creissen, J. Warnan and E. Reisner, Chem. Sci., 2018, 9, 1439-1447.

64 D. H. Nam, J. Z. Zhang, V. Andrei, N. Kornienko, N. Heidary, A. Wagner, K. Nakanishi, K. P. Sokol, B. Slater, I. Zebger, S. Hofmann, J. C. Fontecilla-Camps, C. B. Park and E. Reisner, Angew. Chem., Int. Ed., 2018, 57, 1059510599. 
Submit the annotated PDF file by following this link:

https://rscweb.proofcentral.com/en/offline.html?

token $=09 b 8$ eed35c3ab69618f9793222b298c0 